\title{
Emil Lederer: On the Sociology of World War ${ }^{1}$
}

\author{
Magdalena JÁCHYMOVÁ KRÁLOVCOVÁ
}

magdalena.kralovcova@centrum.cz

Emil Lederer (1882-1939), born in Pilsen (Bohemia, Czech Republic), was an important figure of German social science. A close colleague of Max Weber and friend of Karl Mannheim or J. A. Schumpeter, he taught at universities in Heidelberg, Berlin and Tokyo. After fleeing Germany in 1933, he helped Alvin Johnson, director of the New School for Social Research, found the "University in Exile". Lederer's research centred on contemporary social problems, approaching them in a critical, objective, empirically based way. One of the first to study the new middle classes before World War I, he also dealt with unemployment, technological progress and business cycles. Additionally, his analysis of state and its sovereignty in war lead him to study the question of totalitarianism. The present article aims to present the main ideas of his essay "On the sociology of the First World War" and to celebrate the hundred-year anniversary since its publication.

Written in January 1915, the essay was Lederer's first one and for almost two decades it was the only one to deal with the problems of state and war. Lederer was mainly attracted by what was going on in society and he switched very quickly from one topic to another. Nevertheless his analyses were always sharp and even from our point of view very pertinent. The present essay was published in German in the famous Archive for Social Sciences and Social Politics, an important European review whose editors were Max Weber and Edgar Jaffé. At the time Lederer served as the Archive's secretary and he also taught at the University of Heidelberg. The English version of the essay only appeared in $2006^{2}$ and in his introduction to the English translation Hans Joas says that Lederer's text would deserve to become one of the classic texts of the sociology of war. However, that never happened since the text existed only in German and Lederer has been completely forgotten since his sudden death in 1939. Joas further states that even if the war could have be an occasion for emerging professional social sciences to demonstrate their analytical power and intellectual open-mindedness, the opposite was the case. Most scholars must be characterized as being "remote from reality, unwilling to show any restraint in putting their scientific reputation at the disposal of war propaganda and the construction of enemy stereotypes". According to him there are only few exception and the most important is Emil Lederer. ${ }^{3}$

1 This is a shortened and revised version of paper originaly published by journal Historická sociologie (see: Magdalena JÁCHYMOVÁ KRÁLOVCOVÁ, Stát a společnost pohledem Emila Lederera, in: Historická sociologie, 2010, 1, 103-117).

2 LEDERER, Emil: On the Sociology of World War, in: European Journal of Sociology, 47, 2006, 2, $241-268$.

3 JOAS, Hans: Introduction to "On the sociology of World War", in: European Journal of Sociology, 47, 2006, 2, 241. 
Lederer was personally well aware of the lack of objectivity in contemporary social sciences and stated at the very beginning of his essay, that the war has succeeded in reducing to nothing the small pile of those individuals who are supposed by profession to be "nonpartisan". He explains that he seeks to take up a standpoint outside of the war and to make every effort to gain a position of objectivity in relation to the action of the war making states. His aim is not to discuss the immediate causes of the war but to throw light on the more deep-seated nexus of causes that led to it. ${ }^{4}$

In the first part of his text entitled War technology, Army organization, and Social structure, Lederer borrows the classical dichotomy of society by Ferdinand Toennies. On the day of mobilisation the society (Gesellschaft) becomes a community (Gemeinschaft) because all group-forming influences, all interests, will and actions are suspended and directed toward something communal. This transformation happened not only in Germany, but also in France, Austria-Hungary, Russia and England. ${ }^{5}$ Individual interests are losing their importance and the individual is reduced to be just a part of a whole. This coerced totality exists independently of the will of individuals and it is crushing them wherever they stand. Thanks to the existence of universal conscription the transformation from the state of Gesellschaft to the state of Gemeinschaft is easier than ever before. Modern armies establish a unique military complex, which turns out to be an independent and universal social form having the power to mobilize the people and assign every social force to the cause of national defence. Every social group is incorporated into a unitary army and the individuals do not feel it as an act of coercion by the state but as a transcendental fate. Lederer explains that "everywhere the situation is the same: among each of Europe's peoples, the national Gemeinschaft becomes a community of fate, not a community of actions". ${ }^{6}$

Lederer further continues with war technologies. According to him every significant period in military history reveals distinct forms that are conditioned by prevailing social relations. Not even military experts foresaw the character of this war. Trench tactics played a surprisingly important role; the offensive was overestimated, while the tactical value of the second and third formation lines was underestimated. Unlike in previous wars the first big battles were not decisive for subsequent fighting. Thanks to the devastating firepower of modern weapons troops are driven to the ground, the defence turns out to be the attack at the same time and attackers are forced into defence. War parties are hostages of war technology, which enables that encirclements are so slow that the front lines continually grow longer. Tremendous magnitudes of men and machines are used and battles do not take place at vast spaces. ${ }^{7}$

Lederer defines most distinctive military features of the war: at first the breadth of dispersal and penetrative force of modern munitions, then the mass of manpower, and finally, the advanced level of organisation of modern army. Troops are incorporated into the organized mass of the army and, thanks to the technological level of military complex it is possible to deploy every last part of the available troops. The only real compulsion to conclude

\footnotetext{
4 LEDERER, 2006, 242-243.

5 Ibidem, 244.

6 LEDERER, 2006, 245.

7 Ibidem, 246.
} 
peace is given when the entire human reservoir is exhausted. Modern warfare thus turns to the form of annihilation and extermination. War today culminates in total international war, where only the complete exhaustion of one side can bring a war to an end and where the power of diplomacy is very limited. It is the institute of universal conscription that enables this war of peoples, in the oldest and most horrendous meaning of this term. War's machinery brings about a historic mass homogenization of people given originally as members of differentiated social strata. ${ }^{8}$

Lederer explains that even before the advanced capitalist economy, an early form of competition existed among military apparatus of different states that made human and non-human means of destruction continually expand. An important part is also played by general technological development, in particular in transportation. Therefore the present war is the war of railway lines. Railway enables a mass transport of munitions, men and resources for their deployment and maintenance. From the sociological point of view the principal finding is that in all the participant states, military action has acquired a uniform character and the armies resemble one another not only in their structures and strategies but also in their capabilities of destruction. This is true despite great differences of social structure, cultural character or prevailing ideologies among belligerent states. The cause here again is the existence of universal conscription: armies are composed everywhere of the same types of energies and powers, the war is an affair for everyone and makes all peoples interested in its outcome in exactly the same way. ${ }^{9}$

The second part of Lederer's essay deals mainly with the topic of state and society. According to Lederer the war revealed the double face of modern democratic states: on the one hand, its inward relations are conditioned by the class structure and its domestic action is directly linked causally to socioeconomic circumstances but on the other hand, in its outward relations the modern state is a transmitter of power and a sovereign centre of violence with limitless command and disposal over an entire people and land. ${ }^{10}$ The absolute state did not disappear with the apparition of civil society; it has only essentially altered in nature. In the modern state, the individual has an economic existence; he is seen as possessing a quality of citizenship and therefore a bearer of rights. It is true but only in so far as we speak about inward relations of the state. In its outward relations, it becomes an independent reality with its own intensity and its own goal-directedness. ${ }^{11}$ According to Lederer, the state's limitless power was realized with the establishment of universal military service, which first arrived with French Revolution and was gradually perfected in Prussia. The state gained incomparably greater disposability over the population than the absolute monarch. The modern state exerts power beyond all limits, and remains abstractly the same across all socio-economic differences of populations. The military complex becomes the instrument and substance of the state's power. State and army interacts with one another in such a way that with increasing state power comes a growing army, and with a growing army comes increasing state power. ${ }^{12}$

8 Ibidem, 247.

9 LEDERER, 2006, 248-249.

10 Ibidem, 251.

11 Ibidem, 252.

12 Ibidem, 253. 
The state's dual character appears all the more clearly in the action of its organs. Once war has broken out, no parliament anywhere gains influence over a state's foreign policies and instead becomes purely an organ and instrument of the state in its direct external action. In its foreign relations, the all-powerful state stands forth as the universal organization of the entire social substance, of its entire territory and population, finding in the army a universal social form that cancels all possibility of opposition between the state and society. In war, nothing exists beyond the state, and nothing exists outside of the condition of war. The state takes on a second existence, wholly independent of its domestic arena, which is suspended and reduced. ${ }^{13}$

In the third and last part of his essay, Lederer discusses social and economic conditions of modern war. He does not consider industrialization as the producer or direct cause of the birth of modern state. However, industrialization is essential for imposition of universal conscription. Industrialization enabled the expansion of the demographic reservoir and the increase of productivity. It made it possible to produce sufficient amounts of everyday necessities with much less manpower and in case of mobilization, only with producers unfit for fighting - women, the young and the elderly. Universal conscription in war has decisive economic consequences nevertheless this situation is easier to bear for a modern industrial economy than for an agrarian state. Advanced capitalism is thus essential for its unique capacity to adjust effectively to the exigencies of war, to put up resistance to an enemy, to supply a modern army with all needed articles and to replenish supplies in sufficient quantities during a war progress. On top of that armies and industrial factories are organized in a very similar way and therefore it is very easy to insert industrial workers into military troops: today a soldier's life reflects more closely the psychological habitus of the skilled or unskilled factory worker. Whether for a life in industry or the army, the essence and direction of man's training is the same. Capitalism as the most universal current of our time encompasses the military complex's formation as a phase in its own development. ${ }^{14}$ Lederer is convinced that until the state is not threatened by economic stagnation, the distribution of class power relations is indifferent to the point that even full social democracy can come about without having any influence to a state's foreign power relations. Under capitalism, capital and labour confront one another fundamentally but over and above this antagonism a consciousness of the superiority of the state begins among all social classes. The army as the state's organ of power over its external environment, most fully activated in war, now appears as the expression of the people. Such consciousness of united activity can be described according to Lederer as ideology. In a capitalist society this ideology can only take the form of unity against danger and so in war each state presents itself as the one attacked. This is the only way how to maintain a notion of unity across classes. ${ }^{15}$

The State in war is thus also taking command over domestic intellectual forces. In addition to all official propaganda, surprisingly, all states have seen the bending of public argumentation in favour of war. In this sense, the modern state has become a "cultural state", exploiting all kinds of intellectual and cultural forces. Its tremendous suggestive forces

13 LEDERER, 2006, 253-254.

14 Ibidem, 256-258.

15 LEDERER, 2006, 259. 
enable it to channel cultural life in its own direction; without even the need for coercion over men's minds. A modern state can even shape civil law to its own needs defining itself as the "state of law". In war, no constitution exists in the modern state. The modern state subordinates the individual to its purposes obliterating any independent sphere of inviolable individual right. ${ }^{16}$ Another demonstration of the state's manipulative force is the pusillanimity of intelligentsias and the vanishing of any instinct for reality. Lederer précises that all intellectual and cultural movement in Germany or abroad has been prepared to serve the war as its ideology and sought to exploit it for its own purposes. Suddenly all want the war as their vehicle of consummation and even in Christian circles rare are the voices calling the war un-Christian. ${ }^{17}$ An important role is also played by the idea of nationalism or the concept of Staatsnation - labelled by Lederer as a "fabricated unity of people under one state". The nation, originally an intellectual idea, then an ideology of capitalism, has become nothing but an ideology of the power state. National ideas in all states become an ideology of the state and thereby forfeit all distinctive content. ${ }^{18}$

Lederer further demonstrates that the conception of historical materialism that presents World War I as imperialistic is just a mistake. Whatever economic consequences this war may have, its economic side operates independently of concrete class stratification and economic intention. Different state's capitalist economies have not stood behind the war as active potencies, the war asserts itself over them and they must serve it. This war is not a struggle over sources of raw materials or capital accumulation. In addition, the really important markets of the future, above all China's, are not targets of this war, and all the possible competitors are allies at present. ${ }^{19}$

In his conclusion Lederer stresses that war today is economically conditioned but not economically caused. War is latent in the nature of the modern state. Modern abstract power states with the military complex as their instrument are always already geared to war. They denote war with the same abstractness as their own existence. War today need have no concrete content or goal - not even a cause, only an "occasion". Today the only concrete elements of war are the levels of military organization that operate indifferently in the societal, economic, and cultural arenas. The abstract power state is thus the most advanced form of organized power, and it has achieved a unique importance in world history. ${ }^{20}$

Lederer presents two possibilities how to resolve the situation and the irrevocable dual character of modern state. A utopian alternative would be a socialist system oriented to greater justice in economy, but not necessarily to greater wealth or to greater plenty of resources. However, only a completely changed attitude to economic life might truly attack the power state's imperialistic ideology. The second and last alternative presented by Lederer, is the world alliance of all states in such a way that dynamic conflictual tendencies are denied freedom of movement. A system of organization spread out across the world that deterred states from attacking each other would at least be neutralized in active effect. ${ }^{21}$

16 lbidem, 260.

17 Ibidem, 261.

18 Ibidem, 262.

19 LEDERER, 2006, 263-265.

20 lbidem, 265-266.

21 Ibidem, 267. 
The key element of the Lederer's argumentation about World War I is the existence of universal conscription. It enabled the transformation of society to community; it supplied the army with a mass of manpower that could have been homogenized. Because of universal conscription all armies resemble one another despite the social and cultural differences, they are composed everywhere of the same types of energies and powers. Thanks to universal conscription the modern state is omnipotent - even if its citizens are bearers of civil rights, as soon as the war breaks out they are completely powerless, and therefore the modern state has a double face: it acts differently in its outwards and inwards relations. One of the principal conditions for the existence of universal conscription is the industrialization and modern capitalist economy: it brings not only higher productivity and an abundance of trained industrial workers well suited for military service but also a certain superiority for the state which is experienced as synonymous with the societal domain, so that society continues to feel itself a subject of action even though it has become just an object for the state. Through the medium of the army, society becomes conscious of itself as united in the state's action and this common consciousness is nothing else than ideology. In addition to propaganda, the state has the power to influence all cultural and intellectual forces, to shape civil law, to manipulate all movements, even the Church, and to take use of nationalism as an ideology.

Almost twenty years later, Lederer is again pushed by circumstances to consider the problematic of state and war. After 1933 he was convinced that Hitlerian Germany was going to succeed and start a new world conflict. He fled Germany where he was banished from university for racial reasons, settled in the United States and followed European affairs very closely as a dean of the University in Exile at the New School for Social Research. During those years he published a series of articles about democracy, state, war and freedom ${ }^{22}$. In 1939, several weeks before his sudden death, he started to write a book, "The State of the Masses"23 and there he comes with a completely new point of view at war: this time war is not a distant object of his analysis, war is presented as the only way to defeat the new mass enemy, preserve democratic values and civilization and avoid a new age of slavery. And the very dual character ${ }^{24}$ of the modern state as he described it in 1915 should be considered as a foreboding of the state of the masses.

\section{Abstract}

The present article aims to introduce Emil Lederer (1882-1939) and the main ideas of his essay "On the sociology of the World War". Written in January 1915 this text contains a surprisingly unbiased and unique analysis of the war. Lederer deals with the topics of

22 Emil LEDERER, Freedom and Science, in: Social Research, 1, 1934, 2, 219-231; Emil LEDERER, On Revolutions, in: Social Research, 3, 1936, 1, 1-18; Emil LEDERER, Domestic Policy and Foreign Relations, in: War in Our Time, Hans SPEIER - Alfred KAEHLER (eds.), New York 1939, 43-58; Emil LEDERER, War Economics, in: War in Our Time, Hans SPEIER - Alfred KAEHLER (eds.), New York 1939, 206-221.

23 Emil LEDERER, State of the Masses: The Threat of the Classless Society, New York 1940.

24 D. R. Huebner explains in his article (see: Daniel R. HUEBNER, Toward a Sociology of the State and War: Emil Lederer's Political Sociology, in: European Journal of Sociology, 49, 2008, 1, 70), that Lederer's conception of dual character of the modern state was considered by Ernesst Fraenkel as the very first discovery of the existence of normative and prerogative state, further developed by Fraenkel in his text "The Dual State" from 1941. 
war technology, army organization and social structure, discusses the relationship between state and society and describes social and economic conditions of modern war. The key elements of his argumentation are the existence of universal conscription and the dual character of the modern democratic states.

\section{Keywords}

Emil Lederer, World War I, sociology of war, dual state, universal conscription

\section{References}

HUEBNER, Daniel, R.: Toward a Sociology of the State and War: Emil Lederer's Political Sociology, in: European Journal of Sociology, 49, 2008, 1, 65-90.

JÁCHYMOVÁ KRÁLOVCOVÁ, Magdalena: Stát a společnost pohledem Emila Lederera, in: Historická sociologie, 2010, 1, 103-117.

JOAS, Hans: Introduction to "On the sociology of World War", in: European Journal of Sociology, 47, 2006, 2, 241.

LEDERER, Emil: Zur Soziologie des Weltkriegs, in: Archiv für Sozialwisseschaft und Sozialpolitik, 39, 1915, 2, 347-384.

LEDERER, Emil: Freedom and Science, in: Social Research, 1, 1934, 2, 219-231.

LEDERER, Emil: On Revolutions, in: Social Research, 3, 1936, 1, 1-18.

LEDERER, Emil: Domestic Policy and Foreign Relations, in: War in Our Time, SPEIER, Hans - KAEHLER, Alfred (eds.), New York 1939, 43-58.

LEDERER, Emil: War Economics, in: War in Our Time, SPEIER, Hans - KAEHLER, Alfred (eds.), New York 1939, 206-221.

LEDERER, Emil: State of the Masses: The Threat of the Classless Society, New York 1940.

LEDERER, Emil: On the Sociology of World War, in: European Journal of Sociology, 47, 2006, 2, 241-268. 